\title{
フィブロネクチン含有人工滑液における豚関節骨頭の 摩擦振動特性に関する基礎研究*
}

\author{
石田和 義** 岡 田勝 藏**
}

A Fundamental Study of Vibration Property under Friction at Articular Head of Pig Joint in Artificial Synovial Fluid Containing Fibronectin

\author{
Kazuyoshi ISHIDA and Katsuzo OKADA
}

The purpose of this paper is to determine experimentally the fundamental data of the new artificial synovial fluid, which suppressed the use of sodium hyaluronate (HA). Consequently, a fundamental study is carried out using fibronectin (FN), which is the cell-adhesive proteins that exists in human blood and synovial fluid. The new artificial synovial fluid consisted of FN, dipalmitoyl phosphatidylcholine (DPPC), HA and isotonic sodium chloride solution (I.S.C.S.) as solvent. An evaluation of new artificial synovial fluid is employed by the friction tester with reciprocating slider. In order to verify from an engineering standpoint, the evaluated items are the total amount of wear between the cartilage on articular head of pig joints and the ultra high molecular weight polyethylene (UHMWPE) socket; and the amplitude of vibration which is analyzed with FFT at $80 \mathrm{~Hz}$, the resonant frequency of the movable portion in the friction tester. The results indicated that the artificial synovial fluid containing FN was effective in the reduction of the total amount of wear and the amplitude of vibration. Further, it turned out that the effect of vibrational reduction was better than the effect of wear reduction if $\mathrm{FN}$ is added to artificial synovial fluid. Therefore, the results at an engineering standpoint could confirm that the artificial synovial fluid containing FN had a good performance to the vibration-proof effect.

Key words : fibronectin, wear, vibration, pig joint, artificial synovial fluid

\section{1. 緒言}

人工股関節と人工膝関節を合わせた年間手術件数は，全世界 で約 70 万症例といわれており,日本では人工骨頭挿入術を含め て約 8 万症例である ”。これら人工関節の置換術は人体関節機 能を回復させる最終手段である. 他方, 人工関節置換術を遅ら せる,あるいは関節疾患時の負担を少なくする手段のひとつに， 人体に無害であり，かつ，高い潤滑機能を有する人工滑夜の研 究開発がある。

生体滑液中に含まれ，潤滑特性の向上に関与するヒアルロン 酸ナトリウム $(\mathrm{HA})$, リン脂質, あるいはタンパク質成分など

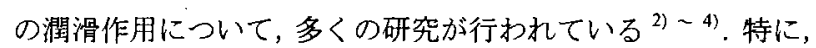
潤滑特性の向上に奇与するHA に関しては，ガンの進行や成長 を促進するという報告 ${ }^{5}$ があるため，安全性の向上を配虑する 場合，関節内投与薬の主成分である HA の使用を抑制すること が必要になる.

そこで本報では，HA の含有量を抑えた新しい人工滑液の開 発に関する基礎資料を求める目的で, HA，リン脂質の一種であ るジパルミトイルホスファチジルコリン (DPPC)，糖タンパク 質成分のフィブロネクチン (FN) を含む生理食塩水内において， 豚関節骨頭一超高分子量ポリエチレン (UHMWPE) ソケットの 組合せで往復すべり摩擦試験機による加速試験を行った．そし て, 摩擦試験中の総摩耗量と, 振動特性を調べることにより, 本人工滑液の有効性を工学的な観点から検証した.

\section{2. 実 験 方 法}

\section{1 実験装置・摺動材}

本研究で用いた往復すべり摩擦試験装置の概略図を図 1 に示

* 原稿受付平成 14 年 10 月 7 日

** 正 会 員 山梨大学工学部（甲府市武田 4-3-11）

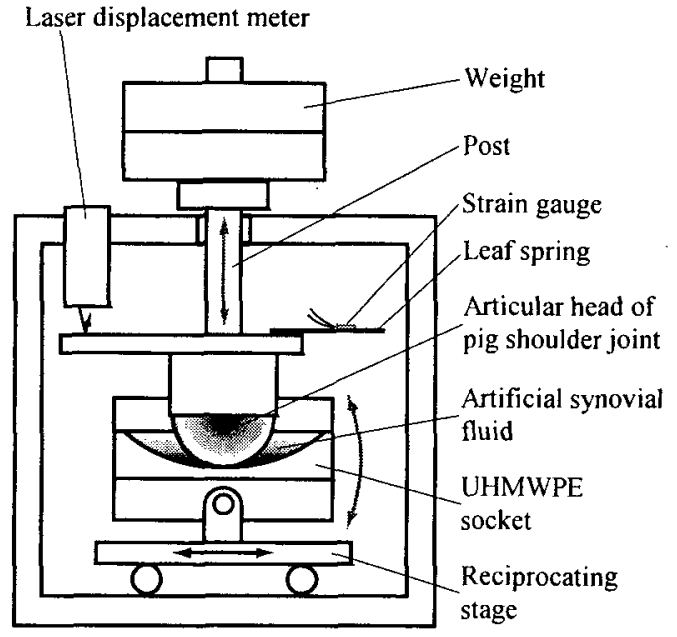

Fig.1 Schematic diagram of the friction tester with vibration measuring

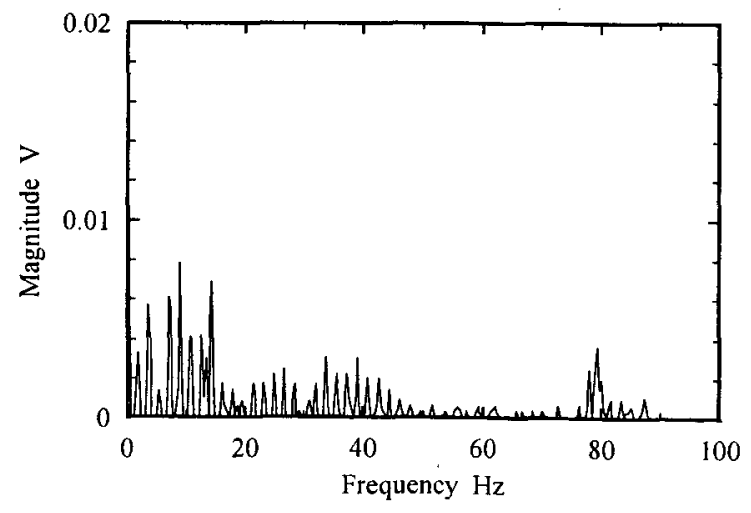

Fig.2 The relationship between magnitude and frequency with FFT 


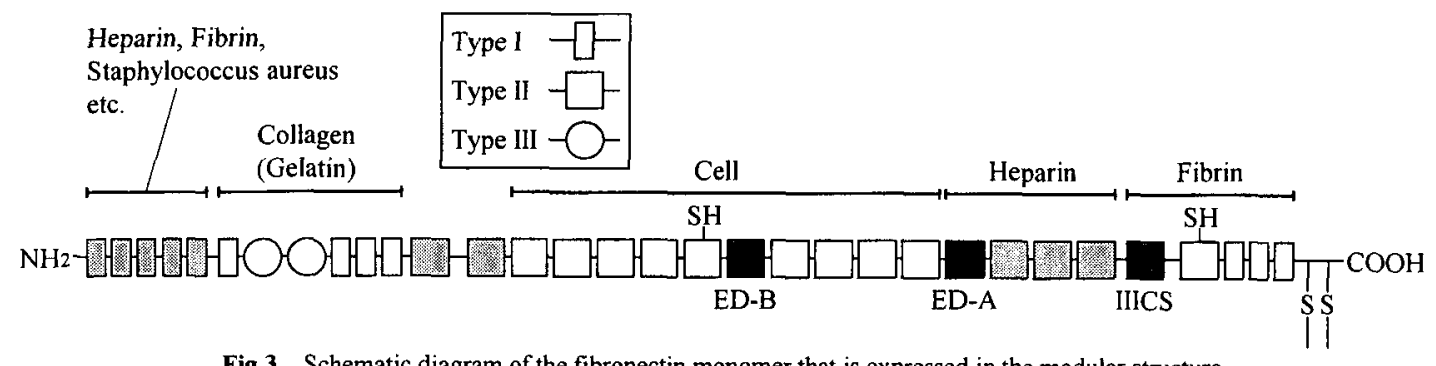

Fig.3 Schematic diagram of the fibronectin monomer that is expressed in the modular structure

Table 1 Constituents of lubricants

\begin{tabular}{|c|c|c|c|}
\hline \multicolumn{3}{|c|}{ Constituents $w t \%$} & \multirow{2}{*}{ Solvent } \\
\hline $\mathrm{HA}$ & DPPC & FN & \\
\hline \multirow{6}{*}{$\begin{array}{c}\text { or } \\
0.1\end{array}$} & & - & \multirow{12}{*}{$\begin{array}{l}\text { Isotonic sodium } \\
\text { chloride solution } \\
\text { (I.S.C.S.) }\end{array}$} \\
\hline & & 0.020 & \\
\hline & & 0.046 & \\
\hline & \multirow{3}{*}{0.001} & - & \\
\hline & & 0.020 & \\
\hline & & 0,046 & \\
\hline 0.3 & \multirow{3}{*}{0.010} & - & \\
\hline & & 0.020 & \\
\hline \multirow{4}{*}{0.5} & & 0.046 & \\
\hline & \multirow{3}{*}{0.100} & - & \\
\hline & & 0.020 & \\
\hline & & 0.046 & \\
\hline
\end{tabular}

す．摺動材の組合せは，豚関節骨頭（豚前肢上腕骨の肩関節骨 頭球面部分, 曲率半径約 $20 \mathrm{~mm}$ ) と，超高分子量ポリエチレン

(UHMWPE) であり，摩耗量の加速を促すためにソケットの内 面を曲率半径 $35 \mathrm{~mm}$ とした. UHMWPE ソケットの平均表面粗 さ $R_{\mathrm{a}}$ は約 $0.8 \mu \mathrm{m}$ である.支柱に取付けられた豚関節骨頭は水平 方向に往復運動する台上に取付けられた UHMWPE ソケット上 に組み込まれており，荷重は支柱を介して豚関節骨頭に付加さ れる. 摩擦条件は, 接触荷重 $200 \mathrm{~N}$, 最大寸べり速度 $40 \mathrm{~mm} / \mathrm{s}$, すべり距離 $20 \mathrm{~mm}$, 往復運動台の振動数 $1.8 \mathrm{~Hz}$, 摩擦時間 4 時間 であり, 約 $30^{\circ} \mathrm{C}$ で実験を行った。

豚関節骨頭一UHMWPE ソケット間の総摩耗量の測定には， 実験装置の支柱方向に取付けたレーザ変位計（最小分解能 $0.1 \mu \mathrm{m}$ ）を用いた。なお，摺動部の摩耗は，主として骨頭表面 上の軟骨で生じた.ここで, 総摩耗量には 5 分間の慣らし運転 後の 30 分毎に求めた初期平均変位と各経過時間における平均 変位の差を定義して用いた，また，摺動面の摩擦に起因する変 位は，支柱動作方向に取付けた板バネ上の歪グージからの信号 を FFT 解析することで求めた。一例として，0.046wt\%フィブロ ネクチン十生理食塩水を滑液とし, 測定開始 3 時間後の FFT 解 析結果を図 2 に示す，同図には，板バネの固有振動数 $14 \mathrm{~Hz}$ と 支柱に固定された可動部の固有振動数 $80 \mathrm{~Hz}$ が認められる。以 下で用いる振動特性は $80 \mathrm{~Hz}$ に関するものである。なお，摩耗 量測定と振動測定は同時に行った。

\section{2 人工滑液}

実験に使用した人工滑液に含まれる, 分子量 60〜80 万のヒア ルロン酸ナトリウム（Sodium Hyaluronate, HA)，リン脂質のジ パルミトイルホスファチジルコリン (Dipalmitoyl Phosphatidylcholine, DPPC)，糖タンパク質のフィブロネクチン

(Fibronectin, FN)，生理食塩水の組成比を表 1 に示す。ここで, $0.01 w t \% D P P C$ は豚滑液の総リン脂質濃度を参考のにした值であ

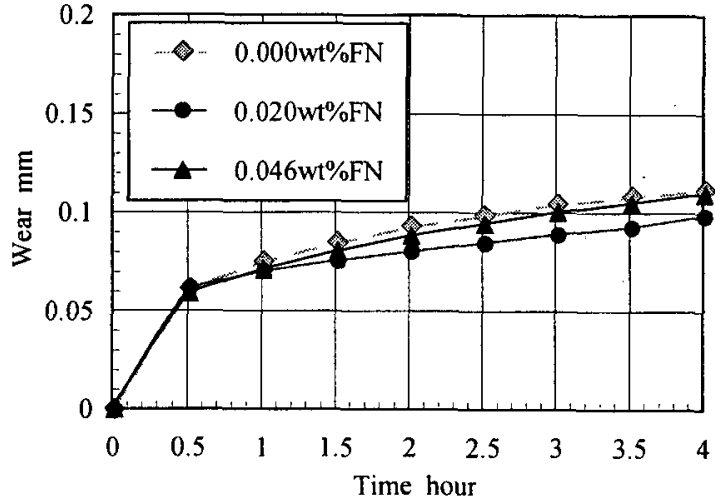

Fig.4 The relationship between wear and time

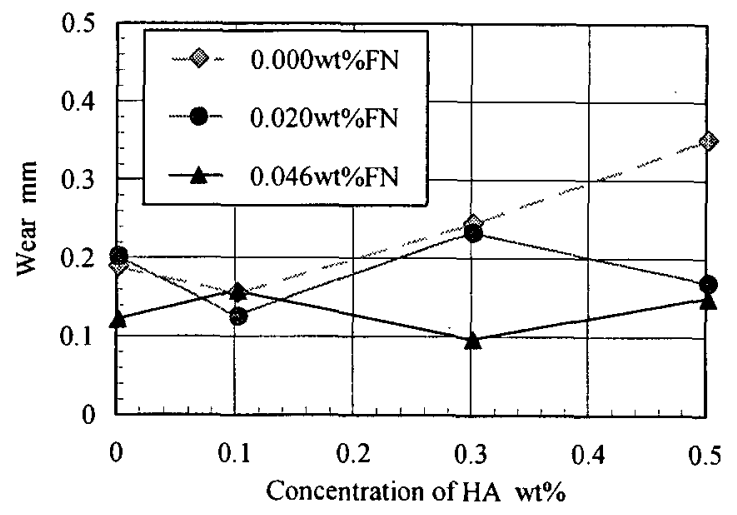

Fig.5 The relationship between wear and concentration of $\mathrm{HA}$

り，FNの 0.020 および $0.046 \mathrm{w} \%$ \%七ト滑液内の生理的濃度と 慢性関節リウマチ時の濃度を想定した值 ${ }^{7}$ である.

FN は, 動物の細胞表面, 結合組織, 血液中などに存在する 分子量約 46 万の糖タンパク質であり, 細胞の接着, 移動, 走化 性, 増殖, 分化, 非特異的感染防御, 創賃治㦄などとの関係が 示唆される ${ }^{8}$. 図 3 に FN の分子構造 ${ }^{9)}$ を示す. FNは 3 種類の モジュールに分類される. Type Iは約45アミノ酸残基からなり， $2 つ の$ S-S 結合（ジスルフィド結合）を含む. Type II は約 60 ア ミノ酸残基によって構成され，Type III は約 90 アミノ酸残基を 含み，S-S 結合はない，FNのリガンド（結合分子）結合部位は FN の一部に保持され，これが分子全体にわたって散在するた め，断片化した FN でも特定のリガンドに結合する ${ }^{10)}$ 特徴を 有する。

本実験で用いた FN 断片は, Sigma-Aldrich 社製の Fibronectin Adhesion-promoting Peptideである.この試薬は分子量 1023, 分 子式 $\mathrm{C}_{47} \mathrm{H}_{74} \mathrm{~N}_{16} \mathrm{O}_{10}$, 純度 $95 \%$, タンパク質含有量䄪 70\%である.

$$
\text { 3. 実 験 結 果 }
$$

\section{1 総摩耗量}




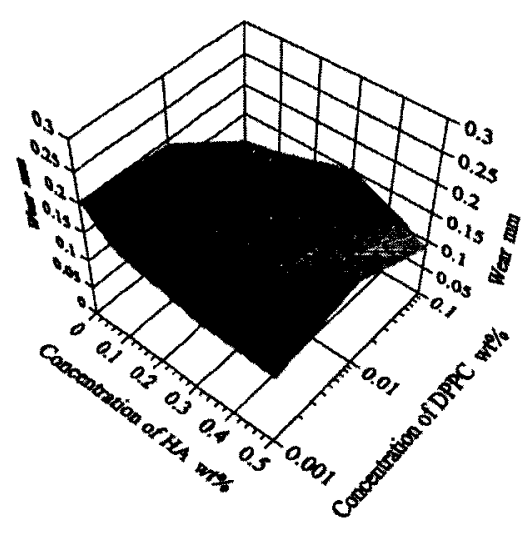

(a) $0.000 \mathrm{wt} \% \mathrm{FN}$

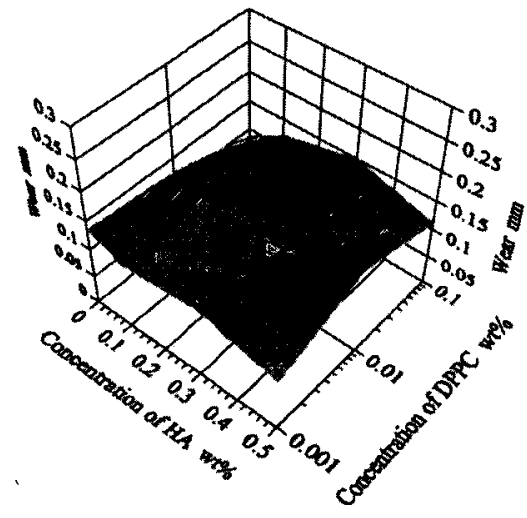

(b) $0.020 \mathrm{wt} \% \mathrm{FN}$

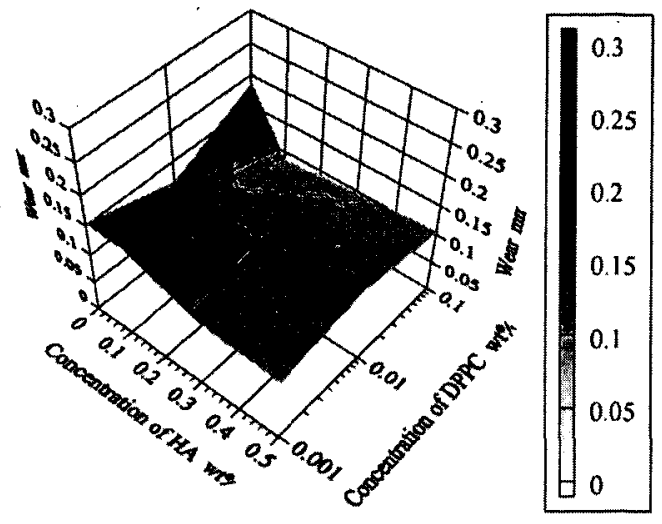

(c) $0.046 \mathrm{wt} \% \mathrm{FN}$

Fig.6 The influences of wear on various concentrations of HA and DPPC that classified into concentration of FN

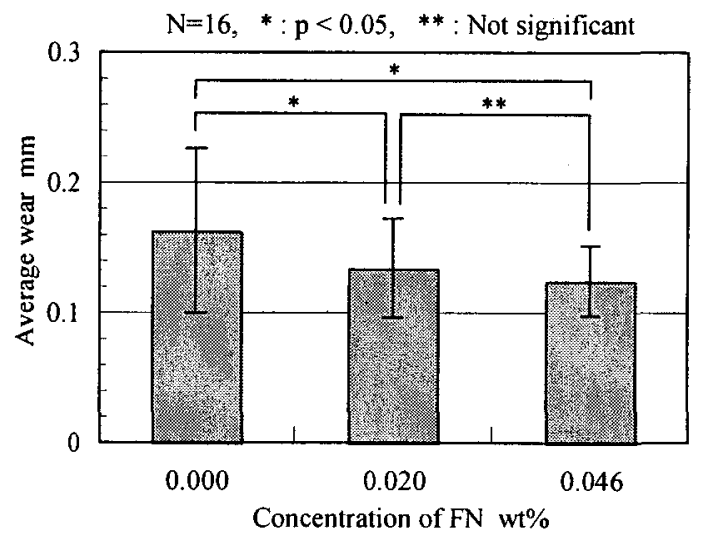

Fig.7 The relationship between average wear and concentration of FN

\subsection{1 時間経過曲線}

図 4 に人工滑液が $0.3 \mathrm{wt} \% \mathrm{HA}+0.010 \mathrm{wt} \% \mathrm{DPPC}+\mathrm{FN}$ である総 摩耗量と経過時間の関倸（摩耗進行曲線）を示す。同図より, FN 添加による総摩耗量の低減が確認でき，0.020wt\%FN 添加の 場合には FN 無添加のものと比較して総摩耗量は 2 割程度減少 していることがわかる。したがって，人工滑液への $0.020 \mathrm{wt} \% \mathrm{FN}$ 添加では，摺動状況を改善する効果が認められる，一方，0.5 時間以後の摩耗進行曲線の傾き，言い換えれば摩耗速度は概ね 一定になっていることが確認できる。これより，0.5 時間以前は 初期摩耗, $0.5 \sim 4.0$ 時間の範囲は定常摩耗であることがわかる.

\subsubsection{FN の影響}

HA および FN を含む人工滑液の各濃度変化が総摩耗量に及 ぼす影響を図 5 に示す.HA のみの人工滑液では, 0.1wt\%HA で 総摩耗量が最小であり, HA 濃度の増加とともに総摩耗量も増 加している. FN のみの人工滑液における総摩耗量は, 0.020 , $0.000>0.046 \mathrm{wt} \% \mathrm{FN}$ であり, $0.046 \mathrm{wt} \% \mathrm{FN}$ では顕著な総摩耗量低 下が確認できる. $0.1 \mathrm{wt} \% \mathrm{HA}$ 含有人工滑液では，FN 濃度の変化 に関係なく総摩耗量はほぼ等しい。0.3wt\%HAでは， $0.046 \mathrm{wt} \% \mathrm{FN}$ の総摩耗量は大幅に減少し，0.5wt\%HA では，FN 添加が総摩耗量の減少に寄与することが確認される.

ここで, $0.046 \mathrm{wt} \% \mathrm{FN}$ 添加のとき摩耗量は, FN 無添加と比較 して有意に低減した $(p<0.05)$ ，なお， $p$ は有意水準を示す。一 方, $0.020 \mathrm{wt} \% \mathrm{FN}$ 添加と FN 無添加との有意差はなかった. した がって, HA 含有人工滑夜に 0.046wt\%FN を添加すれば総摩耗 量が低減することより，高濃度 FN は潤滑状態の改善に有効で あることがわかる。

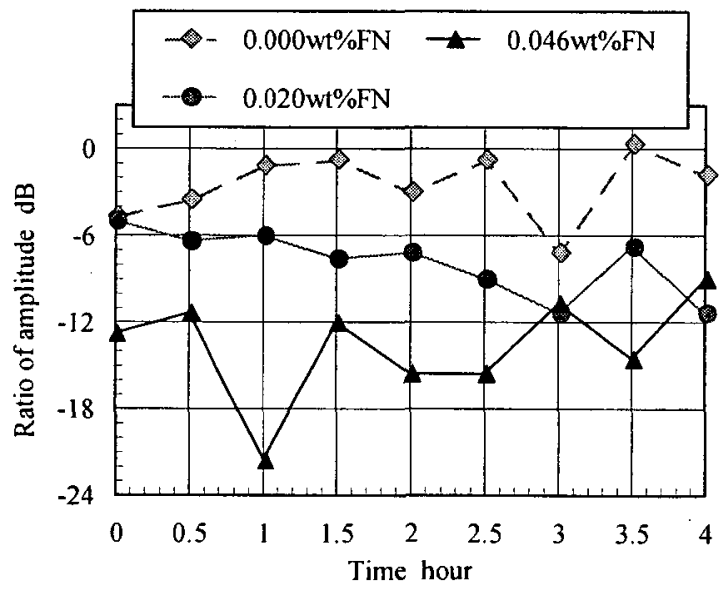

Fig.8 The relationship between the ratio of amplitude and time

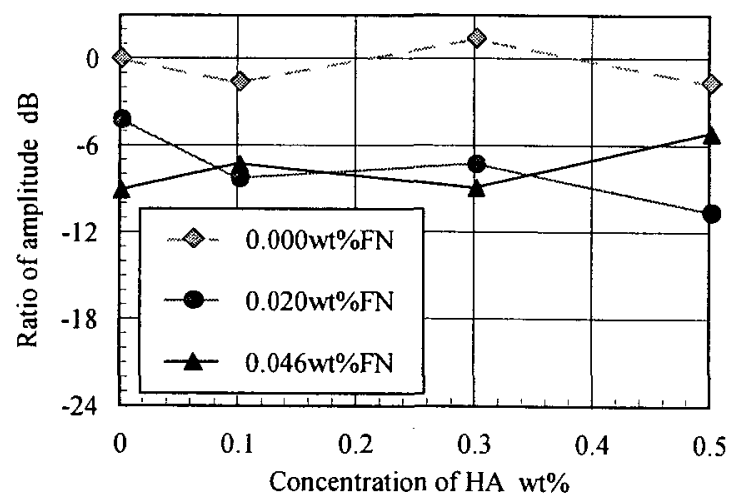

Fig.9 The relationship between the ratio of amplitude and concentration of HA

\subsubsection{3 成分（FN, DPPC, HA）の影響}

FN 濃度が $0.000 \mathrm{wt} \%, 0.020 \mathrm{wt} \%, 0.046 \mathrm{wt} \%$ であるときの総摩 耗量と DPPC，HA 濃度との関係を図 6 に示す。同図より， $0.000 \mathrm{wt} \% \mathrm{FN}$ のさの総摩耗量は, $0.10 \sim 0.20 \mathrm{~mm}$ の範囲であり， $0.020 \mathrm{wt} \%$ よび $0.046 \mathrm{wt} \% \mathrm{FN}$ のときのそれは，ともに 0.10 ～ $0.15 \mathrm{~mm}$ の範囲である. 以上の結果より，(1) FN 無添加の場合， DPPC や HA 濃度が総摩耗量の低下をもたらすこと，(2) FN の 添加においても，総摩耗量を減少させることがわかる. 特に, FN 添加による総摩耗量の低減が $0.001 \sim 0.01 w \% \mathrm{DPPC}+0.0 \sim$ $0.1 w t \% H A$ において顕著であることから; FN の添加は低濃度 HAにおいて有効であることが裏付けられる.

図 5 および図 6 の総摩耗量を FN 濃度毎に算術平均して得た 


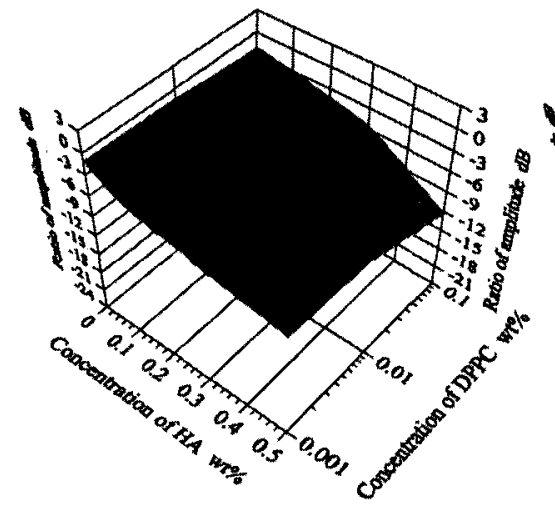

(a) $0.000 \mathrm{wt} \% \mathrm{FN}$

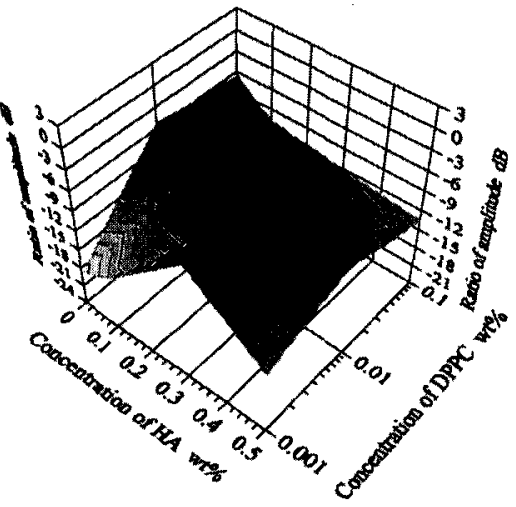

(b) $0.020 \mathrm{wt} \% \mathrm{FN}$

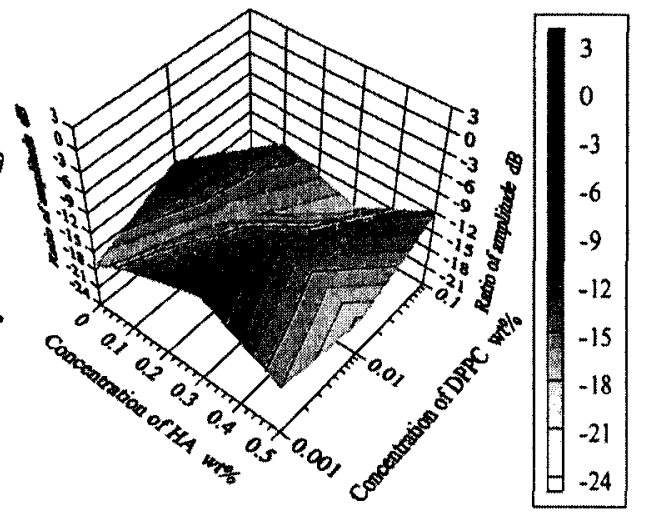

(c) $0.046 \mathrm{wt} \% \mathrm{FN}$

Fig.10 The influences of the ratio of amplitude on various concentrations of HA and DPPC that classified into concentration of FN

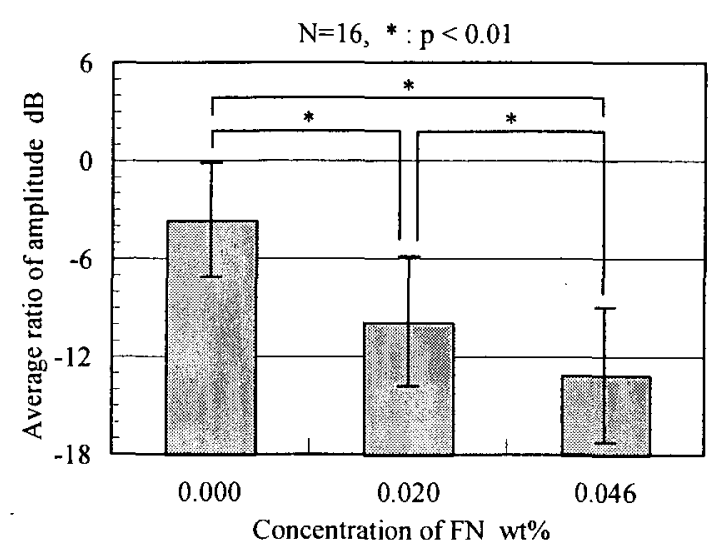

Fig.11 The relationship between the average ratio of amplitude and concentration of FN

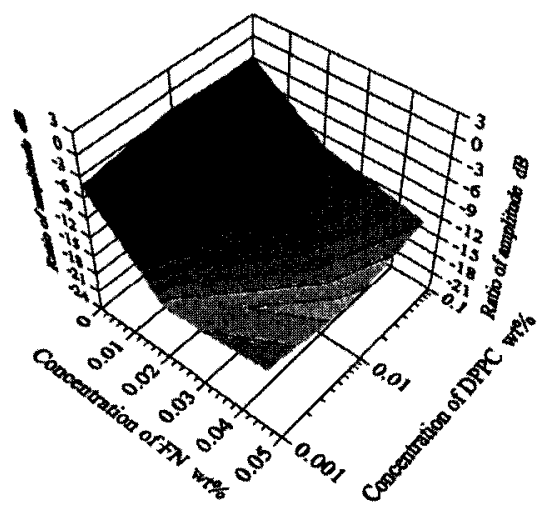

(a) $0.1 w t \% \mathrm{HA}$

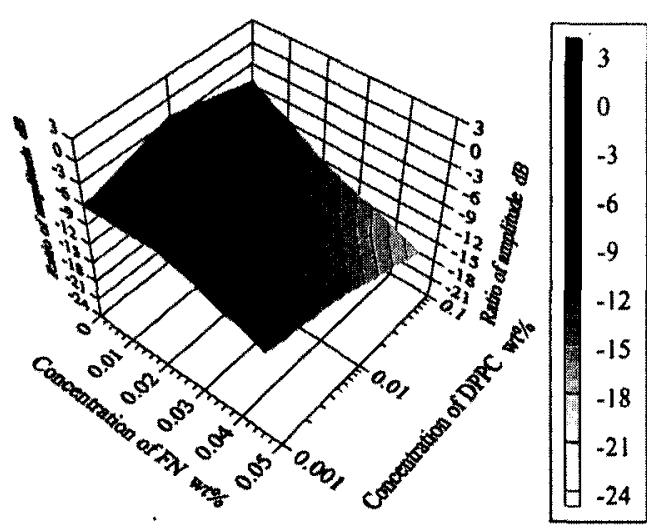

(b) $0.3 w t \% \mathrm{HA}$
Fig.12 The influences of the ratio of amplitude on various concentrations of FN and DPPC that classified into concentration of HA
合において，潤滑液に生理食塩水のみを用いた時の振幅を基準 とした，振幅比と経過時間の関係を図 8 に示す. 同図より，い ずれの FN 濃度でも時間の経過に伴って振動比は変動するが, FN 濃度が高いほど振幅比は減少し，振動抑制効果が顕著であ ることを確認できる.

\subsubsection{FN の影響}

全測定時間における振幅比の算術平均値と HA 濃度の関係を 図 9 に示す．同図より，(1) FN 添加は振幅比を 4〜9dB 程度減 少させること，(2) 同じ FN 濃度であれば，振幅比は HA 濃度 に依存せず，概ね一定であり，0.000wt\%, 0.020wt\%, 0.046wt\%FN のときの平均振幅比は，順に-0.5dB, -7.6dB, -7.6dB であること，

(3) $0.020 \mathrm{wt} \% \mathrm{FN}$ と $0.046 \mathrm{wt} \% \mathrm{FN}$ の振幅比では顕著な相違が確 認できないこと，がわかる。これらより，HA 含有人工滑液一 の僅かな FN 添加が振動抑制効果に大きく影響することがわか る。

3.2.3 3 成分 (FN, DPPC, HA) の影響

FN 濃度を $0.000 \mathrm{wt} \%, 0.020 \mathrm{wt} \%$, $0.046 \mathrm{wt} \%$ と固定した場合の振幅比 と HA および DPPC 濃度との関係を 図 10 に示す，FN 無添加の同図 (a) では，HA 濃度の増大が振動低減効 果をもたらし，0.3wt\%HA 以上では -6dB になるが， $0.3 \mathrm{wt} \% \mathrm{HA}$ 以上の濃 度では，振動低減効果はほとんど確 認できない. 同図 (b) の 0.020wt\%FN の場合，振動比-6dB 以下の HA およ び DPPC 濃度範囲では，全濃度範囲 において，FN 添加による振動低減 効果が確認できる。同図（c）の $0.046 \mathrm{wt} \% \mathrm{FN}$ の場合，ほぼ全濃度範 囲において，振幅比が-12dB 以下で

あり，FN 添加に起因する著しい振動低減効果が確認できる， 以上まとめると，次のようになる.

（1）FN 添加は著しい振動低減効果を示寸が，DPPC 添加によ る振動低減効果は僅かである.

（2） $0.020 \mathrm{wt} \%$ およで $0.046 \mathrm{wt} \% \mathrm{FN}$ の振幅比は $0.020 \mathrm{wt} \%>$ $0.046 \mathrm{wt} \%$ であり，FN 濃度が大きいほど振動低減効果は増 大する。

図 9, 図 10 から求めた, FN 濃度と平均振幅比の関係を図 11 


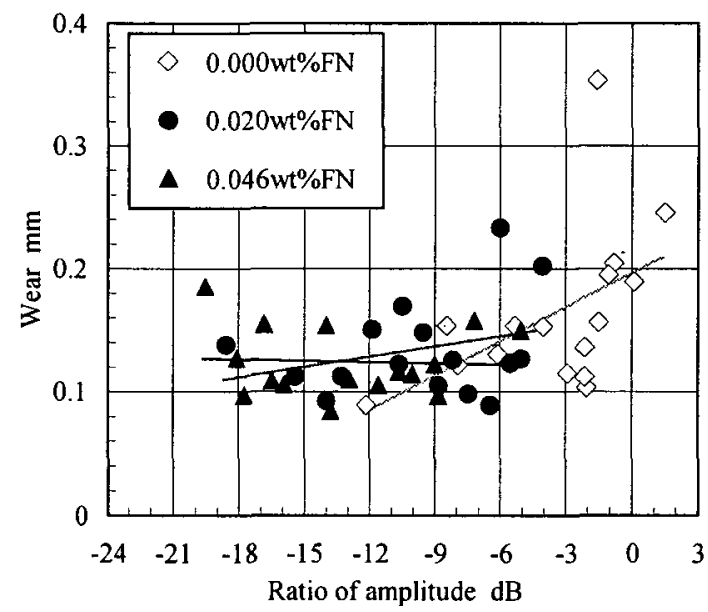

Fig.13 The relationship between wear and the ratio of amplitude

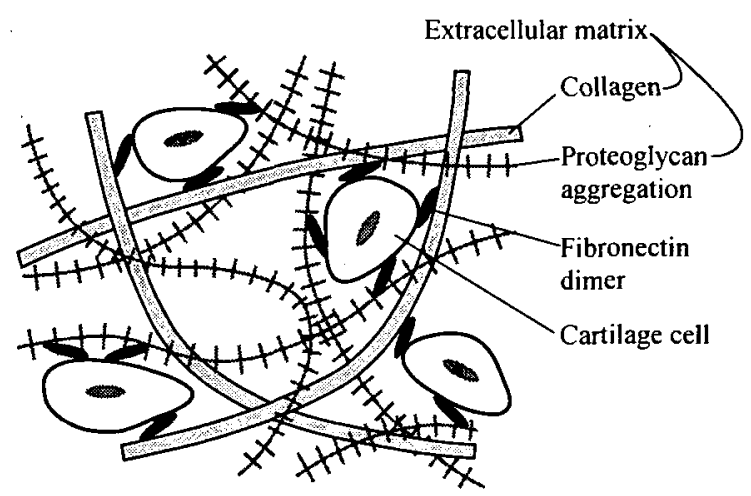

Fig.14 Schematic diagram of a surficial region on the cartilage born

に示す．同図より，FN 濃度の上昇に伴って振幅比は減少する 傾向を示すことが確認できる.

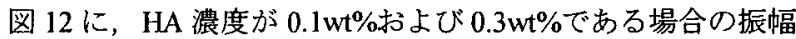
比と FNおよびDPPC 濃度との関係を示す.同図 (a)の0.1wt\%HA では，振幅比は DPPC 濃度に依存せず FN 濃度の堌加に伴って 減少している.また，同図 (b) の $0.3 w t \% H A$ では, $0.1 w t \% D P P C$ において FN 濃度増加による振幅比の大きな低減が確認できる。 なお， $0.1 \mathrm{wt} \% \mathrm{HA}$ と $0.3 \mathrm{wt} \% \mathrm{HA}$ の場合， $0.020 \mathrm{wt} \% \mathrm{FN}$ および $0.046 \mathrm{wt} \% \mathrm{FN}$ 添加したときの振幅比は， FN 無添加のそれと比較 して有意に減少した $(p<0.05)$ ，一方， $0.5 \mathrm{wt} \% \mathrm{HA}$ では，FN 添 加と FN 無添加の振幅比における有意差は無かった。したがっ て, 低濃度 HA における FN 添加は, 振動の低減効果に有効で あることが確認できた。

\section{4. 考察}

各 FN 濃度における,振幅比と総摩耗量の関倸を図 13 に示す。 同図より，(1）FN 無添加の場合，振幅比の減少に伴い，総摩 耗量は减少する僋向を示すが，(2） $0.020 \mathrm{wt} \% \mathrm{FN}$ では振幅比の 減少に伴う総摩耗量の減少が鈍くなり，(3) $0.046 \mathrm{wt} \% \mathrm{FN}$ では 振幅比の増減に関倸なく，総摩耗量はほぼ一定值であることが 確認できる，同図における $0.000 \mathrm{wt} \% ， 0.020 \mathrm{wt} \% ， 0.046 \mathrm{wt} \% \mathrm{FN}$ の相関係数は，順に，0.51，0.29，-0.06であることから，FN 濃 度上昇に伴い相関係数の絶対值が減少することがわかる。これ より，人工滑液に FN を添加すれば, 摩耗低減効果よりも振動 低減効果が顕著になることが確認できる。

FN は生体組織内で線維状を呈しながら会合し，細胞外マト
リックスの線維状高分子（コラーゲン，フィブリン，グリコサ ミノグリカンなど）と結合する ${ }^{11)}$ が，関節軟骨の表面では図 14 の様相を呈しているもの ${ }^{12)}$ と考えられる。同図において， 複雑に絡み合う長鎖状のコラーグン・プロテオグリカンの会合 体と軟骨細胞との結合が FN の接着効果で強化される機構を仮 定するならば，軟骨表面層では衝撃力の吸収作用が増大するも のと推定される.

以上より，FN を人工滑液一添加することで，豚関節骨頭の 軟骨表面は，耐摩耗性や耐振動性を有する摺動界面に改質され ることを工学的な実験により明らかにした，特に振動特性に関 しては, 図 11 に示した測定結果より顕著な防振効果が認められ ることから，軟骨表面の改質が推測される．さらに，図 12 (a) が示すように，HA の含有量を抑えた場合についても，FN 添加 による大幅な振動低減効果が確認できるため, FN はHA の部分 的な代替添加剤の一候補に挙げることができる。

\section{5. 結喜}

往復すべり摩擦試験機を用いて, FN, DPPC, HA を含む生理 食塩水内における豚関節骨頭-UHMWPE ソケット間の総摩耗 量および摺動中に発生する振動を測定した，その結果，以下の 結論を得た。

（1）HA 含有人工滑液への $0.046 \mathrm{wt} \% \mathrm{FN}$ 添加は総摩耗量を低減 させる。

(2) DPPC ・ HA 含有人工滑液への FN 添加は，平均総摩耗量を 18〜24\%减少させる.

（3） HA 含有人工滑液への FN 添加は，振動の振幅比を 4 9dB 程度低減させる。

(4) FN・DPPC・HA 含有人工滑液において, FN は著しい振 動低减効果を示すが，DPPC の振動低減効果は小さい。

（5）低濃度 HAにおけるFN 添加は，振動の低減効果に有効で ある。

\section{謝辞}

本研究の実験にご協力いただいた，山梨大学大学院生の伏見 羽置君に感謝する。

\section{参 考 文 献}

1）大森健一：人工関節における製品開発戦略，日本機械学会誌，104, 11(2001)15-18.

2）日垣秀彦，村上輝夫：関節潤滑における関節液と軟骨表層の構成成 分の役割（第 1 報），トライボロジスト，39、7(1994)625-632.

3）日垣秀彦, 村上輝夫, 中西義孝, 三浦裕正, 馬渡太郎, 岩本幸英: 関節潤滑におけるリン脂質の役割，日本臨床バイオメカニクス学会 誌, 18, (1997)237-242.

4）日垣秀彦，村上輝夫 : 関節潤滑における関節液と軟骨表層の構成成 分の役割（第 2 報），トライボロジスト，40，7(1995)598-604.

5) A. LLaneza et al. : Hyaluronic acid as prognostic marker in resectable colorectal cancer. British Journal of Surgery 2000, 87, 1690-1696.

6）日垣秀彦, 村上輝夫，中西義孝: 生体関節における蛋白成分とリン 脂質の境界潤滑作用，日本機械学会論文集 (C 編)，61， 588(1995)3396-3401.

7) 林正男 : 新 細胞接着分子の世界，羊土社，(2001)36.

8）日経バイオテク編: 日経バイオ最新用語辞典, 日経 BP 社, (1995)594.

9) Jean E Schwarzbauer, \& Jan L Sechler : Fibronectin fibrillogenesis: a paradigm for extracellular matrix assembly, Current Opinion in Cell Biology, 11(1999)622-627.

10) 林正男 : 新 細胞接着分子の世界, 羊土社, (2001)38.

11）林正男：新 細胞接着分子の世界, 羊土社, (2001)37.

12）笹田直, 塚本行男, 馬㴊清資: バイオトライボロジ, 産業図書, (1988)40。 